PREHISTORY OF THE RUSTLER HILLS Granado Cave 


\section{Prehistory of}

\section{DONNY L. FFMmTON}

\section{Contributions by}

John R. Bratten

David L. Carlson

John E. Dockall

Cristi Assad Hunter

Harry J. Shafer

Texas Archaeology and

Ethnohistory Series

THOMAS R. HESTER, EDITOR 


\section{the Rustler Hills}

\section{GRANADO CAVE}

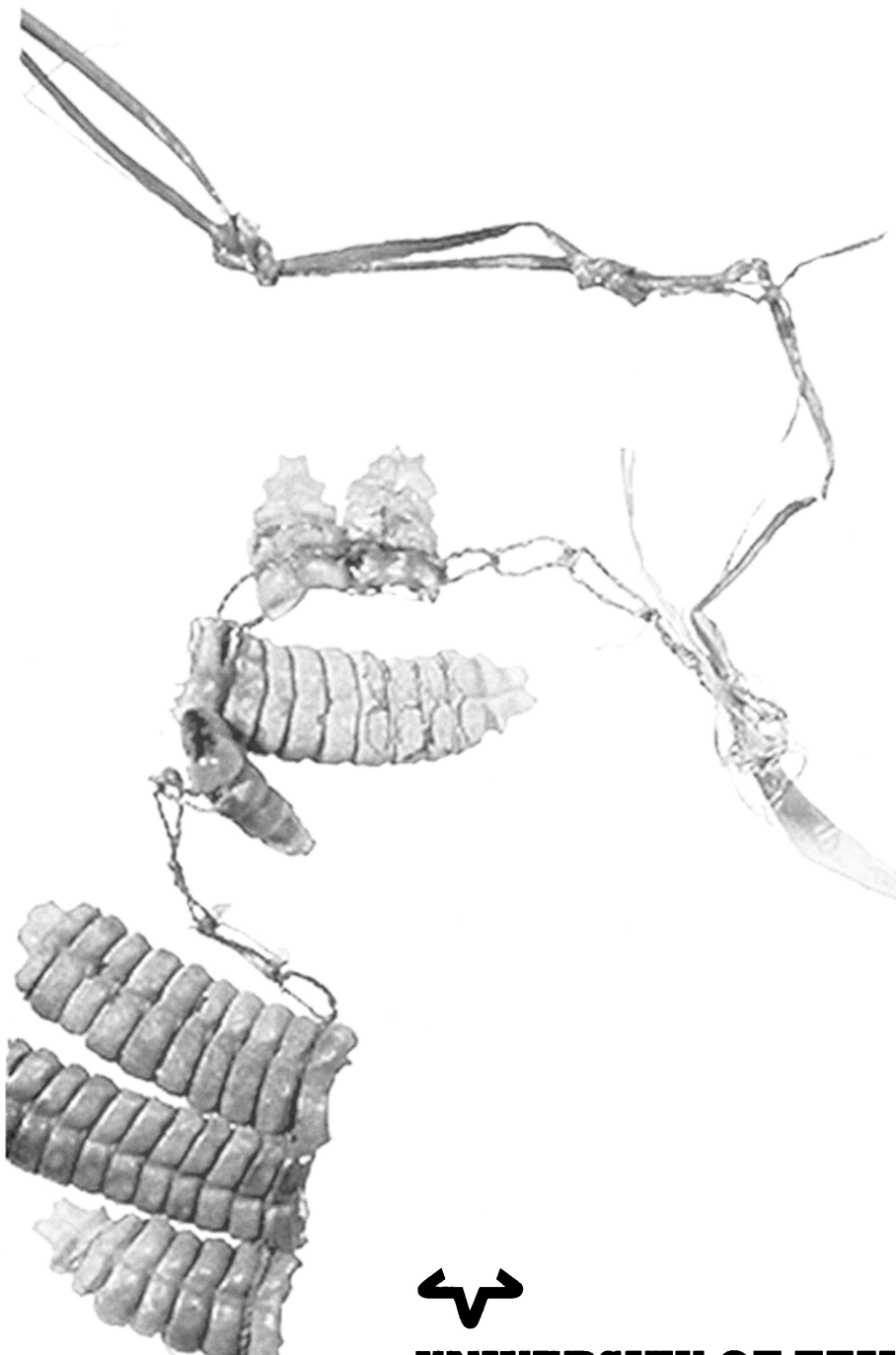

UNIVERSITY OF TEXAS PRESS AUSTIN 
The Granado Cave excavations were funded by the Texas Historical Foundation and J. O. Hayhurst. This report was submitted to the Texas Historical Commission in September 1998, under Texas Antiquities Permit Number 177.

Copyright (c) 2001 by the University of Texas Press

All rights reserved

Printed in the United States of America

First edition, 200I

Requests for permission to reproduce material from this work should be sent to Permissions, University of Texas Press, Box 7819, Austin, TX 78713-7819.

\section{Libraxy of Congress Cataloging-in-Publication Data}

Hamilton, Donny Leon.

Prehistory of the Rustler Hills : Granado Cave / Donny L. Hamilton ; contributions by John R. Bratten ... [et al.]. - Ist ed.

p. cm. - (Texas archaeology and ethnohistory series) Includes bibliographical references and index. ISBN 0-292-73I4I-8 (hardcover)

I. Granado Cave (Tex.) 2. Indians of North America-Texas-Antiquities. 3. Indians of North America-Guadalupe Mountains (N.M. and Tex.)Antiquities. 4. Indians of North America-Material culture-Guadalupe Mountains (N.M. and Tex.) 5. Excavations (Archaeology)-Guadalupe Mountains (N.M. and Tex.) 6. Guadalupe Mountains (N.M. and Tex.)Antiquities. I. Bratten, John R. II. Title. III. Series.

E78. T4 HI9 2OOI

$976.4^{\prime} 94-\operatorname{dc} 2$ I

oo-008892

A rattlesnake-rattler rattle found in Granado Cave. Ink drawing by Helen Dewolf.

ISBN 978-0-292-75802-5 (library e-book)

ISBN 978-0-292-78885-5 (individual e-book) 
I dedicate this to my wife,

\section{Betsy Preston Hamilton}

who had nothing to do with the writing, but

who gave up the most

so that it could be written. 
THIS PAGE INTENTIONALLY LEFT BLANK 